\title{
Teaching information literacy Developing an online course for faculty
}

A $s$ part of the profession's ongoing efforts to integrate information literacy into the curriculum, some librarians have taken an approach centered on teaching disciplinary faculty to teach information literacy. Indeed, some have argued that the best way for librarians to ensure that students are developing information literacy is to focus primarily on faculty, rather than on providing instruction to students. ${ }^{1}$ Although most librarians do not seem prepared to stop all direct instruction to students, there are many examples of libraries offering faculty development programming. ${ }^{2}$ While many of these programs involve faceto-face interactions between librarians and disciplinary faculty, there are examples of librarians creating online information literacy workshops or courses for faculty. ${ }^{3}$

In this article I will outline the development of an online, self-paced information literacy course, intended to help course instructors incorporate information literacy into their teaching practices. I will consider the benefits and challenges of online faculty development, and also provide recommendations for anyone considering developing their own course.

At an institution the size of The Ohio State University, ensuring that all students are receiving information literacy instruction can be challenging. Librarians and staff from the University Libraries provide course-integrated and cocurricular instruction, consult with instructors, and teach credit-bearing courses. However, with more than 60,000 students, it is not possible for librarians to provide direct instruction or consultation in all courses where it might be needed. And while our credit courses have good enrollment, they still reach only a small fraction of the student population.

As another approach to supporting the integration of information literacy into the curriculum, the Libraries' Teaching and Learning Department also focuses on providing instructor development programs and resources. An opportunity to develop in-depth programming arose when the University Institute for Teaching and Learning (UITL) began offering teaching endorsements, credentials provided to faculty who participate in professional development programming in specific areas. Since the program began, the Teaching and Learning Department has developed two endorsements, one of which is Teaching Information Literacy, a fully online course, accessed through Canvas, which is intended to teach faculty how to purposefully integrate information literacy into courses.

\section{Course design and development}

The first step in developing Teaching Information Literacy was the creation of a detailed project plan, which provided a

Jane Hammons is teaching and learning engagement librarian at The Ohio State University's University Libraries, email: hammons.73@osu.edu

(c) 2020 Jane Hammons 
rationale for why the endorsement was needed, indicating how it aligned with the Libraries' strategic directions and identifying desired outcomes. Among these outcomes were creating an expanded understanding of information literacy among faculty, highlighting the Libraries' role in supporting teaching and learning, and improving the information literacy development of Ohio State's students.

The course design process then began with background analysis, including a learner and context analysis, with special consideration of faculty as learners. I also reviewed the literature to identify best practices for faculty development in the online context. Melissa Rizzuto's recommendations for the design of online, selfpaced courses for faculty were especially valuable. ${ }^{4}$

Following the backward design process developed by Grant Wiggins and Jay McTighe, I began identifying the learning outcomes for the participants. ${ }^{5}$ I considered questions such as: What are the enduring understandings that participants should take away? What should they be able to do after completing the course? In answering these questions, the following learning outcomes were identified:

- develop an expanded understanding of information literacy as a concept,

- explore how the purposeful teaching of information literacy skills and concepts can improve student learning,

- use the Framework for Information Literacy for Higher Education to identify gaps in student knowledge related to research, scholarship, and information use,

- identify information literacy learning outcomes that connect to existing course learning outcomes, and

- employ instructional design strategies to develop or revise an assignment or activity in order to teach information literacy.

Once the overall learning outcomes were identified, I created a course plan outlining the specific learning outcomes for each module, the topics that would be covered, and potential activities and assessments, and then began developing the content.

Throughout the design and development process, I continually sought feedback from others in Teaching and Learning, including the department's instructional designer. After a good amount of course content had been created, I sought a more formal assessment. Several colleagues reviewed the course and provided detailed feedback through a survey and discussions. Based on their responses, I revised the course to increase learner engagement. Finally, the course was approved to be offered as an endorsement after roughly ten months of development.

\section{Course content}

The course consists of six modules, designed to be completed over 12 hours. ${ }^{6}$ Each module starts with a scenario, describing a specific challenge that a student or instructor is experiencing. The first scenario, for example, introduces a student who has tried to locate good sources, but is frustrated when his instructor tells him the sources are not scholarly. At the end of each scenario, participants post their reaction to a discussion board. They are encouraged to refer to their past experiences as a way to connect the scenario to their own situations. After posting their responses, participants proceed through the different pages of the module. Pages include a mix of text, videos, slides, and links to outside readings. At the end of each page, there are questions that encourage participants to reflect on the content or a list of key takeaways for the participants. Each module ends with reflection questions, which encourage participants to think about how they might apply what they have learned to their own teaching.

The first module provides a foundation for the rest of the course by demonstrating the complexity of the information environment. In the second and third modules, participants are introduced to the Framework for 
Information Literacy for Higher Education. ${ }^{7}$ In the fourth module, after briefly outlining the backward design process, participants identify information literacy learning outcomes. As part of this, learners are introduced to the Decoding the Disciplines model. ${ }^{8}$ Participants also respond to a series of questions, based on those developed by Sara D. Miller, ${ }^{9}$ which are intended to help them identify their own tacit disciplinary knowledge in the context of the Framework, and to highlight the ways in which this hidden knowledge may contribute to information literacy learning bottlenecks. In the fifth module, participants review examples of Framework-based assignments, and then outline their own assignment or activity. Participants also learn about the Transparency in Learning and Teaching (TILT) framework, developed by Mary-Ann Winkelmes, which emphasizes the need for clarifying the purpose, criteria, and tasks for research assignments. ${ }^{10}$

The major assignment is the creation of an Information Literacy Action Plan. ${ }^{11}$ Participants download the action plan template in Module 1, and then (at various times throughout each module) are prompted to add to their plan. In the final module, they revise their plan before submission. This allows participants leave the course with specific steps they can take to integrate information literacy into a course.

\section{Benefits, challenges, and recommendations}

In the first four months, more than 30 participants enrolled, including assistant and associate professors, lecturers, librarians, and graduate teaching assistants. While this still is a relatively small number, promotion has been minimal. However, I have recently begun working with the Libraries' Marketing and Communications Department to develop a strategy to increase awareness of the course. Among those who have participated, feedback has been positive. One of the participants was so excited by the content that she has since contacted me for support in redesigning a course around the Framework.
Taking an online approach to teaching instructors about information literacy has several benefits. At Ohio State, many faculty development programs are offered in the weeks immediately before or after a semester, when faculty have time. In the Teaching and Learning Department, these were already busy times. In addition to participating in professional development programs offered by other units on campus, the department offers a 2 1/2-day workshop series focused on supporting instructors' efforts to design equitable research assignments. Trying to add another multiday workshop at the same time did not seem feasible. In addition, Ohio State has multiple campuses, and it can sometimes be challenging for instructors from regional campuses to attend programs on the Columbus campus. Creating an online course gave us the ability to expand our instructor development offerings and reach a wide group of instructors, across multiple campuses, without having to limit our participation in other programs. For faculty, the online format provides the flexibility to participate in programming at a time that is most convenient for them.

While creating an online course provides benefits, it can also create challenges, especially with a self-paced format. Some participants have started the course and then stalled. Without deadlines, participants may turn their attention to more pressing matters, and the course may fall off their radar. Another challenge is that, since participants can start at any time, those who are active in the course may be at very different places, limiting the potential for participant-to-participant interaction. To address some of these issues, I am considering modifications that would include establishing starting and ending dates for cohorts of participants. Enrolling at the same time as several others may encourage more interaction, while adding a completion deadline would potentially support more sustained engagement. Participants would still be allowed to work at their own pace within the enrollment period, so the course would retain the benefit of flexibility. 
As it can take a significant amount of time to develop such a course, it is important to think carefully about whether such effort is justified. For those who are considering following a similar path, here are a few recommendations:

- Determine if such a course is aligned with the strategic directions for your library. If you are going to put in the work, you will want to be sure that it will help your library to support its goals.

- Think about how you will gain the interest of your target audience. At Ohio State, we are lucky to be able to offer the course as a teaching endorsement. While not all libraries will have a similar option, there may be other ways that you can incentivize instructors to participate.

- Ensure enough time for design and development, including learner and context analysis, so that you can develop a course that will work for your learners and your institution.

- Conduct formative assessment. If possible, get the opinion of a few nonlibrarians.

- Keep in mind that participants will be instructors who want practical guidance for how they can improve their teaching. Be sure that they will come away with real strategies that they can use in their courses.

\section{Conclusion}

Creating an online information literacy course for faculty may seem daunting, as it requires moving into the realms of instructional design and faculty development. However, it can bring great benefits for both librarians and course instructors. At Ohio State, the Teaching Information Literacy course helps to enhance the visibility of the University Libraries as a partner in teaching and learning. While there are no plans for Ohio State librarians to stop providing instruction to students, instructor development programming is an additional way that librarians can support students' information literacy.

\section{Notes}

1. Risë L. Smith, "Philosophical Shift: Teaching the Faculty to Teach Informa- tion Literacy," paper presented at the 8th National ACRL Conference, Nashville, April 11-14, 1997, www.ala.org/acrl /publications/whitepapers/nashville/smith (accessed February 7, 2020); William Miller and Steven Bell, "A New Strategy for Enhancing Library Use: Faculty-Led Information Literacy Instruction," Library Issues 25, no. 5 (May 2005); Sandra Cowan and Nicole Eva, "Changing Our Aim: Infiltrating Faculty with Information Literacy," Communications in Information Literacy 10, no. 2 (2016): 163-177.

2. For a few recent examples, see Sherri Saines, Sara Harrington, Chad Boeninger, Paul Campbell, John Canter, and Bryan McGeary, "Reimagining the Research Assignment: Faculty-Librarian Collaborations that Increase Student Learning," College \& Research Libraries News 80, no. 1 (2019), 14-17, 41, https://doi.org/10.5860/ crln.80.1.14; Elizabeth Dolinger, "Defining and Teaching Information Literacy: Engaging Faculty and the Framework," College $\&$ Research Libraries News 80, no. 1 (2019), 10-13, 21, https://doi.org/10.5860 /crln.80.1.10; Stephanie Crowe, Anne Pemberton, and Vonzell Yeager, "Information Literacy Faculty Fellows Program: Building a Faculty-Librarian Framework Community of Practice," College \& Research Libraries News 80, no. 5, 285-288, https://doi. org/10.5860/crln.80.5.285.

3. For examples, see Erin McCaffrey, Tina J. Parscal, and Tom Riedel, "The Faculty-Librarian Connection: An Online Workshop," Journal of Library Administration 45, no. 1-2 (2006), 297-300, https://doi. org/10.1300/J111v45n01_16; Grace L. Veach, "Teaching Information Literacy to Faculty: An Experiment," College \& Undergraduate Libraries 16, no. 1 (2009), 58-70, https://doi. org/ 10.1080/10691310902753983; Robert Miller, Edward O’Donnell, Neal Pomea, Joseph Rawson, Ryan Shepard, and Cynthia Thomes, "Library-led faculty workshops:

(continues on page 349) 
Baldwin Library), Stephanie Birch, Suzanne Stapleton, Sara Russell-Gonzalez (Science librarian), Lourdes Santamaria-Wheeler (exhibits director), Rebecca Jefferson (head of Judaica Library), Keith Manuel (public services associate), Hunter McDaniel (Baldwin library assistant), and Jeanne de Villeneuve (high school intern from Paris).

\section{Notes}

1. S. C. Stapleton, M. Royster, N. Bharti, S. Birch, J. Bossart, S. Butts, T. T. Cataldo, S. R. Gonzalez, V. Minson, S. Putnam, and C. Yip (2019), "Girls Tech Camp: Librarians inspire adolescents to pursue STEM careers," Issues in Science and Technology Librarianship 92 (Fall).

2. About Westwood: https://fl02219191. schoolwires.net/domain/6699.

3. Westwood Middle School (GreatSchools. org): https://www.greatschools.org /florida/gainesville/12-Westwood -Middle-School/\#Low-income_students*Test _scores*Civics.

4. Alachua County Public Schools 21st Century Community Learning Centers (21CCLC): https://fl02219191.schoolwires. net/Page/135.

5. 21CCLC: https://www.sbac.edu /domain/7034.

6. Public K-12 Education, K-20 Education Code, Florida Statutes: www.leg. state.fl.us/statutes/index.cfm?App _ $\operatorname{mode}=$ Display_Statute $\&$ Search _ String = \& U R L = $1000-1099 / 1003$ /Sections/1003.42.html.

7. Breakout EDU, https://store. breakoutedu.com/.

8. Cheryl Alexaitis, personal communication, 12/5/2019.

("Teaching information literacy," continues from page 340)

Helping distance educators meet information literacy goals in the online classroom," Journal of Library Administration 50, no. 7-8 (2010), 830-856, https://doi.org/10.1080 /01930826.2010.488977.

4. Melissa Rizzuto, "Design Recommendations for Self-Paced Online Faculty Development Courses," TechTrends: Linking Research \& Practice to Improve Learning 61, no. 6 (2017), 77-86.

5. Grant Wiggins and Jay McTighe, Understanding by Design (ASCD, 2005).

6. While the full course can only be accessed through Ohio State's course management system, an overview of the course modules is available at https://go.osu.edu /teachinfolitshared.

7. Association of College and Research Libraries, "Framework for Information Literacy for Higher Education," www.ala.org/acrl /standards/ilframework (accessed February 14, 2020).

8. Joan Middendorf and David Pace, "Decoding the Disciplines: A Model for Helping Students Learn Disciplinary Ways of
Thinking," New Directions for Teaching and Learning 2004, no. 98 (2004): 1-12; Decoding the Disciplines, "Decoding the Disciplines: Improving Student Learning," http://decodingthedisciplines.org/ (accessed March 6, 2020).

9. Sara D. Miller, "Diving Deep: Reflective Questions for Identifying Tacit Disciplinary Information Literacy Knowledge Practices, Dispositions, and Values through the ACRL Framework for Information Literacy," The Journal of Academic Librarianship 44, no. 3 (2018): 412-418, https://doi.org/10.1016/j.acalib.2018.02.014.

10. Mary-Ann Winkelmes, "Transparency in Teaching: Faculty Share Data and Improve Students' Learning," Liberal Education 99, no. 2 (2013); TILT Higher Ed, "TILT Higher Ed Examples and Resources," https://tilthighered.com/tiltexamplesandresources (accessed March 6, 2020).

11. To view the Information Literacy Action Plan template, go to https://go.osu. edu/teachinfolitshared. $\boldsymbol{z}$ 